\title{
PRODUCTION OF "ECTOPIC" VASOACTIVE INTESTINAL PEPTIDE-LIKE AND NEUROTENSIN-LIKE IMMUNOREACTIVITY IN HUMAN PHEOCHROMOCYTOMA CELL CULTURES ${ }^{1}$
}

\author{
ARTHUR S. TISCHLER, ${ }^{* 2}$ YING C. LEE, $\ddagger$ ROBERT L. PERLMAN,§ DONNA COSTOPOULOS,* \\ VAL W. SLAYTON,* AND STEPHEN R. BLOOM $\$$ \\ * Department of Pathology, Tufts University School of Medicine, Boston, Massachusetts 02111, $\$$ Department of Medicine, \\ Hammersmith Hospital, Royal Postgraduate Medical School, London W120HS, England, and $\S$ Department of Physiology and \\ Biophysics, University of Illinois College of Medicine, Chicago, Illinois 60680
}

Received November 2, 1983; Accepted January 1, 1984

\begin{abstract}
Neoplastic chromaffin cells from human pheochromocytomas can exhibit extensive spontaneous and nerve growth factor (NGF)-induced outgrowth of neurite-like processes in vitro, despite the absence of such processes in vivo. To determine whether acquisition of neuron-like features by human pheochromocytoma cells in culture is accompanied by functional alterations, process outgrowth, vasoactive intestinal peptide-like immunoreactivity (VIPLI), neurotensin-like immunoreactivity (NTLI), and catecholamine content were studied in freshly dissociated cells and in 21day-old cultures from six human pheochromocytomas. All of the cultures produced VIPLI and exhibited spontaneous process outgrowth. NGF stimulated process outgrowth and enhanced production of VIPLI. Dexamethasone inhibited process outgrowth and tended to decrease production of VIPLI. NTLI was detected in cells from only one of the tumors, and its production appeared to be regulated comparably to that of VIPLI. Catecholamine content decreased markedly in all of the cultures and was not regulated in parallel with either VIPLI or NTLI. The findings suggest that human pheochromocytoma cultures may help to elucidate cellular and molecular mechanisms regulating ectopic and normal VIP production.
\end{abstract}

Vasoactive intestinal peptide (VIP) is a regulatory peptide present in a number of different types of neurons in the central and peripheral nervous systems (Said, 1982). VIP is generally undetectable in normal adrenal chromaffin cells of humans and other mammals (Linnoila et al., 1980). However, human adrenal pheochromocytomas may produce abundant "ectopic" VIP capable of causing a severe diarrheal syndrome (Said, 1976; Bernard et al., 1980).

Neurotensin (NT) is a regulatory peptide which, like VIP, is distributed in diverse central and peripheral neurons (Leeman and Carraway, 1982). In addition, NT is found in the normal adrenal medulla of rats and cats (Rokaeus, et al., 1982) and in the PC12 rat pheochromocytoma cell line (Tischler et al., 1982a, 1983b, c). The

\footnotetext{
${ }^{1}$ This research was supported by American Cancer Society Grant PDT-171, National Institutes of Health Grants CA27808 and HL29025, and the Medical Research Council. We thank Ms. Linda Callahan and Ms. Erin O'Rourke for secretarial assistance and Mr. Stephen Halpern for photographic work.

${ }^{2}$ To whom correspondence should be addressed.
}

content of NT in PC12 cells is increased by nerve growth factor (NGF), which also causes the cells to form neuritelike processes (Greene and Tischler, 1976), and by dexamethasone, which also increases catecholamine content (Tischler et al., 1983d). NT is not detectable in the normal human adrenal medulla (Rokaeus et al., 1982) and has not been reported in human pheochromocytomas.

It has been known for some time that cultured neoplastic chromaffin cells from human pheochromocytomas can exhibit extensive spontaneous and NGF-induced outgrowth of long processes similar to those of NGF-treated PC12 cells (Tischler et al., 1976) despite the absence of such processes in vivo. Recently, Mendelsohn et al. (1979) suggested that such transition from chromaffin cell to neuron-like phenotype might be accompanied by increased production of VIP. The study reported here was performed to test this hypothesis and to determine whether changes in VIP content of human pheochromocytoma cells in vitro are accompanied by parallel changes in catecholamine content. In view of the morphological similarities of human pheochromocytoma 
cells to PC12 cells in culture, the content of NT was also investigated.

\section{Materials and Methods}

Tissue from six adrenal pheochromocytomas was obtained at surgery. Each tumor was diagnosed as a typical pheochromocytoma from multiple histological sections by at least two pathologists using accepted morphological criteria. Four of the tumors were sporadic, and two (numbers 1 and 3) were from patients with familial multiple endocrine neoplasia. All of the patients were adults, and none had the watery diarrhea, hypokalemia, and achlorhydria syndrome (Verner and Morrison, 1958) associated with VIP-producing neoplasms. Tumor tissue was minced in $\mathrm{Ca}^{++}$and $\mathrm{Mg}^{++}$-free Hanks' balanced salt solution (CMF-HBSS) and dissociated either by incubation for $2 \mathrm{hr}$ at $37^{\circ} \mathrm{C}$ in collagenase (Sigma Type II, 3 $\mathrm{mg} / \mathrm{ml}$ in CMF-HBSS supplemented with $1.25 \mathrm{mM}$ $\mathrm{CaCl}_{2}$ ) or mechanically by trituration with a Pasteur pipette. The latter method proved to be at least an order of magnitude less efficient than enzymatic dissociation. Dissociated cells were suspended in McCoy's 5A medium with $20 \%$ fetal bovine serum and $50 \mu \mathrm{g} / \mathrm{ml}$ of gentamycin.

Replicate aliquots of dissociated cells from each tumor were plated and cultured for 21 days in collagen-coated (Bornstein, 1958) Falcon tissue culture dishes in routine medium or in medium supplemented with $2.5 \mathrm{~S}$ mouse salivary gland NGF $(100 \mathrm{ng} / \mathrm{ml})$ and/or dexamethasone disodium phosphate $\left(10^{-5} \mathrm{M}\right)$. At this concentration, dexamethasone increases catecholamine content in $\mathrm{PC1} 2$ cells (Tischler et al., 1983d) and in normal adult rat chromaffin cells (Tischler et al., 1982b). Additional sets of identical cell aliquots were harvested immediately to be assayed for VIP-like and NT-like immunoreactivity (VIPLI and NTLI) and for catecholamines. Tumors 1 to 3 were plated at low density (approximately $10^{5}$ cells/ dish), which permitted subsequent counting of cells and processes. Tumors 4 to 6 were plated at high density (approximately $10^{6}$ cells/dish), which permitted subsequent normalization of VIPLI, NTLI, and catecholamine content against cell protein. Cultures were incubated at $37^{\circ} \mathrm{C}$ in a water-saturated atmosphere at $95 \%$ air and $5 \%$ $\mathrm{CO}_{2}$, with medium changes three times per week. A final medium change was performed $24 \mathrm{hr}$ before harvest. On day 21 in vitro, VIPLI and NTLI were again measured both in cell extracts and in culture medium from each dish, and cell extracts were again assayed for catecholamines. In addition, process outgrowth and tumor cell survival under the different sets of culture conditions were quantitated for three of the tumors by strip counts performed by phase contrast microscopy (Greene and Tischler, 1976; Tischler et al., 1982a).

For the harvests at day 21, the medium was removed from each dish, supplemented with aprotinin (Sigma, final concentration 500 kallikrein inhibitor units (KIU)/ $\mathrm{ml}$ ), boiled for $5 \mathrm{~min}$, frozen, and lyophilized. The cells were washed three times in HBSS, scraped from the culture dishes in ice-cold, aprotinin-supplemented phosphate-buffered saline, $\mathrm{pH} 7.2$, and sonicated. Aliquots were taken for catecholamine and protein determinations. The remainder was boilcd for $5 \mathrm{~min}$, supplemented with radioimmunoassay grade bovine serum albumin
(Sigma, final concentration $1.5 \%$ ), and centrifuged at $12,000 \times g$ for $5 \mathrm{~min}$ in an Eppendorf microcentrifuge. The supernatant was then frozen and lyophilized. For the harvests on day 0 , the dissociated cells in suspension were centrifuged at $300 \times g$ for $5 \mathrm{~min}$, washed three times in HBSS, and then treated identically to the cells on day 21. VIPLI and NTLI were measured in reconstituted lyophilized cell extracts and medium by previously described radioimmunoassays using whole molecule-directed antibody against synthetic porcine VIP (Mitchell and Bloom, 1978) and C-terminal-directed antibody against synthetic bovine NT (Blackburn and Bloom, 1979). Chromatographic analyses were also performed on cell extracts from two of the 21-day-old NGF-treated cultures (tumors 5 and 6) using a Sephadex G50 superfine column $(0.9 \times 60 \mathrm{~cm})$ calibrated with dextran blue, cytochrome $c$, and $\mathrm{Na}^{125} \mathrm{I}$ as molecular size markers. The column was eluted with $0.06 \mathrm{M}$ phosphate buffer, $\mathrm{pH} 7.0$, containing $0.3 \%$ human serum albumin and $0.2 \mathrm{M} \mathrm{NaCl}$, and $0.9-\mathrm{ml}$ fractions were collected. Catecholamines were measured by high pressure liquid chromatography (HPLC) with electrochemical detection, as previously described (Erny et al., 1981). Protein was measured by Spector's modification (Spector, 1978) of the Bradford Coomassie blue method (Bradford, 1976).

\section{Results}

As previously described (Tischler et al., 1976), pheochromocytoma cells were readily recognized as polygonal, phase-dark epithelial-like cells which usually formed clusters and which to varying degrees gave rise to thin, branching, varicose processes similar to those of cultured neurons (Fig. 1).

On day 21 in vitro, all cultures from all of the six tumors exhibited spontaneous process outgrowth. This outgrowth was stimulated to varying degrees by NGF, as previously reported, and was inhibited by dexamethasone (Table I, Fig. 1). Numbers of tumor cells per dish decreased to approximately one-third to one-twelfth of initial numbers during the 21 days in vitro, and the different culture conditions caused no significant differences in tumor cell survival (Table I). Most of the cell losses appeared to occur during the first few days in culture.

Cells from all of the tumors showed markedly increased content of VIPLI after 21 days in vitro, whether expressed per culture dish or per microgram of cell protein (Table II). Culturing in routine medium with no additives caused the appearance of VIPLI in cells from four tumors in which none was detectable at the time of plating, despite the initial presence of larger numbers of cells. Culturing in routine medium also increased the content of VIPLI in cells from two tumors which did contain small amounts at the time of plating (numbers 1 and 4). NGF-treated cultures contained approximately 2 to 10 times as much total VIPLI as those without additives. Dexamethasone tended to decrease the amount of VIPLI, in contrast to NGF, but individual tumors varied in this respect. In one case (tumor 2), dexamethasone-treated cultures contained more VIPLI in both cells and medium than did control cultures. In another case (tumor 6), 

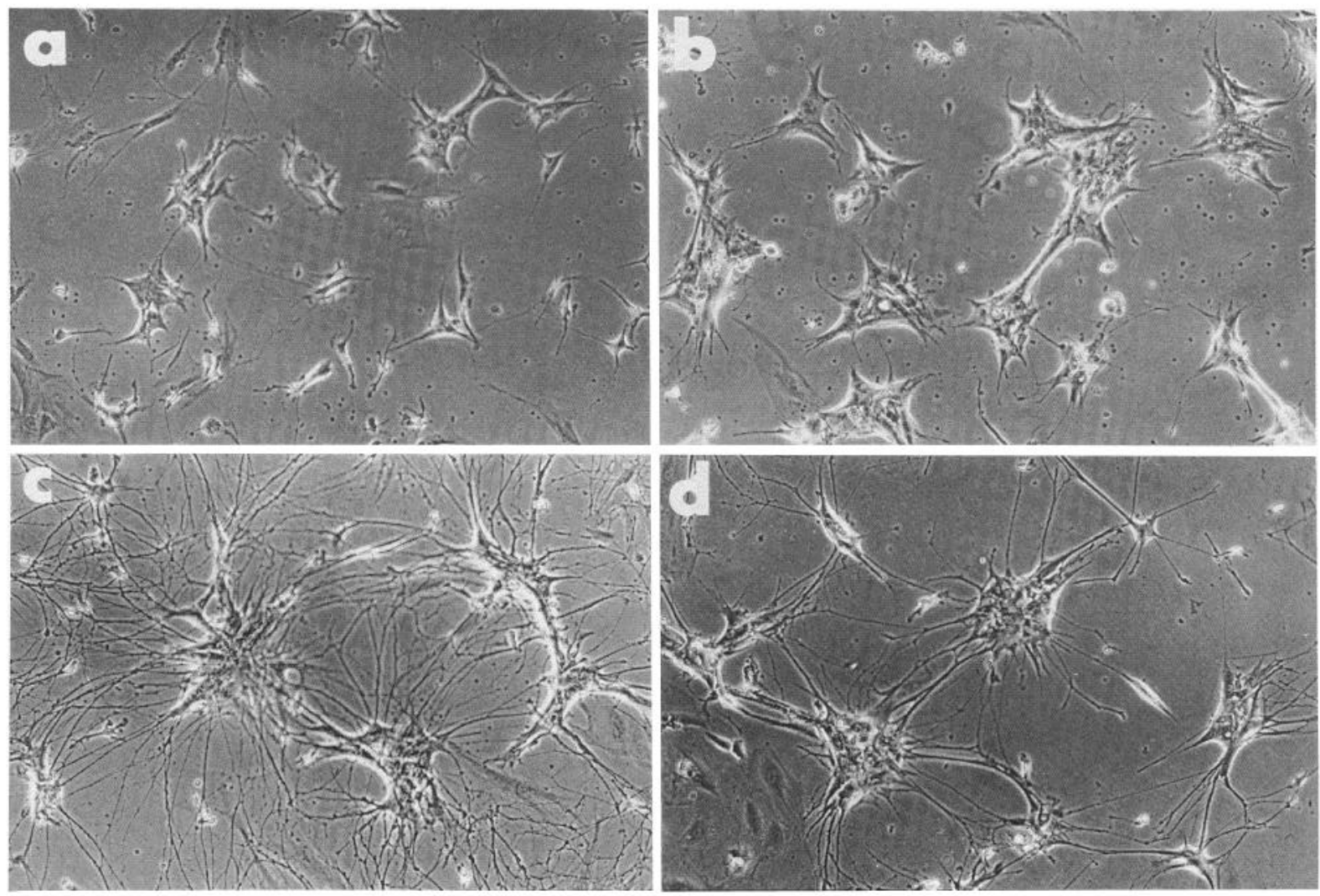

Figure 1. Representative phase contrast photomicrographs of live cultures from tumor 4 under different culture conditions at day 21 in vitro. $a$ illustrates cells grown in routine medium; $b$, with dexamethasone; $c$, with NGF; $d$, with NGF + dexamethasone. Tumor cells occur predominantly in clusters, which show varying degrees of process outgrowth. Rare fibroblast-like cells are also present, most notably in the lower left of $d$ (Magnification $\times 64)$.

TABLE I

Effects of culture conditions on process outgrowth and cell survival

Values represent mean \pm SEM. Counts were derived by scoring all tumor cells in two to six diagonal strips totaling 1 to $3 \%$ of a culture dish surface area ( 210 to 887 cells) for each set of culture conditions. NGF-induced increases in process outgrowth are highly significant in cases 1 and $2(p<0.001)$ but not in case 3 . In all cases, however, processes in NGF-treated cultures appeared to be longer and to branch more extensively than those in cultures without additives (see Fig. 1). Cell numbers per dish decrease to approximately one-third to one-twelfth of original numbers between day 0 and day 21, but no differences in cell survival between different sets of culture conditions for any of the tumors are statistically significant at day 21 .

\begin{tabular}{|c|c|c|c|c|c|}
\hline \multirow{3}{*}{ Tumor } & \multicolumn{5}{|c|}{ Process Outgrowth and Cell Number } \\
\hline & \multirow{2}{*}{ Day 0} & \multicolumn{4}{|c|}{ Day 21} \\
\hline & & No Additives & NGF $(100 \mathrm{ng} / \mathrm{ml})$ & Dexamethasone $\left(10^{-5} \mathrm{M}\right)$ & NGF + Dexamethasone \\
\hline $\begin{array}{l}\text { 2. Cells with processes (\%) } \\
\text { Cells per dish }\end{array}$ & 69,000 & $\begin{aligned} 20 & \pm 2 \\
24,800 & \pm 2,854\end{aligned}$ & $\begin{aligned} 42 & \pm 3 \\
23,733 & \pm 3,180\end{aligned}$ & $\begin{aligned} 5 & \pm 1 \\
28,533 & \pm 2,533\end{aligned}$ & $\begin{aligned} 9 & \pm 1 \\
26,133 & \pm 4,068\end{aligned}$ \\
\hline
\end{tabular}

dexamethasone decreased the amount of VIPLI in the cells while increasing that in the medium.

In contrast to VIPLI, detectable NTLI was produced by cells from only one of the six tumors. In cells from tumor 5, small quantities of NTLI were detected at the time of plating. Content of NTLI in these cells increased at least 4 -fold by day 21 in medium with no additives and, like VIPLI, was increased by NGF and decreased by dexamethasone (Table III). Virtually all of the VIPLI or NTLI in cells from tumor 5 co-eluted, respectively, with synthetic VIP or NT standards (Figs. 2 and 3). The VIPLI in cells from tumor 6 eluted as two peaks containing, respectively, $74 \%$ and $26 \%$ of the total. The former peak co-eluted with synthetic VIP, while the latter consisted of larger molecular forms (Fig. 4). Recovery was $72 \%$ for VIPLI and $95 \%$ for NTLI.

In contrast to the large increases in VIPLI or NTLI, catecholamine content in the same culture dishes decreased to approximately one-eighth to one-eightieth of initial levels per microgram of cell protein and to one- 
TABLE II

Effects of culture conditions on VIP-like immunoreactivity in cells and medium

Values represent mean \pm SEM of triplicate dishes or mean of duplicate dishes. Tumors 1 to 3 were plated at densities of approximately $10^{5}$ cells/dish (see Table I) and tumors 4 to 6 were plated at approximately $10^{6}$ cells ( 350 to $1000 \mu \mathrm{g}$ of protein)/dish. At least $80 \%$ of the cells in the high density culture dishes were estimated to be tumor cells at the time of harvest (see Fig. 1). Culturing pheochromocytoma cells in control medium tends to increase VIP-like immunoreactivity, whether calculated per dish or per microgram of protein, and this increase is markedly enhanced by NGF. Dexamethasone tends to decrease VIP-like immunoreactivity, but characteristics of individual tumors appear to be variable in this respect.

\begin{tabular}{|c|c|c|c|c|c|}
\hline \multirow{3}{*}{ Tumor } & \multicolumn{5}{|c|}{ Immunoreactive $\mathrm{VIP}^{a}$} \\
\hline & \multirow{2}{*}{ Day 0} & \multicolumn{4}{|c|}{ Day 21} \\
\hline & & No Additives & $\mathrm{NGF}(100 \mathrm{ng} / \mathrm{ml})$ & Dexamethasone $\left(10^{-5} \mathrm{M}\right)$ & NGF + Dexamethasone \\
\hline $\begin{array}{l}\text { 1. Cells (fmol/dish) } \\
\text { Medium (fmol/dish/24 hr) }\end{array}$ & $58.3 \pm 15.3$ & $\begin{array}{l}262.3 \pm 35.5 \\
185.6 \pm 12.9\end{array}$ & $\begin{array}{l}957.0 \pm 196.1 \\
163.4 \pm 13.1\end{array}$ & $\begin{array}{l}26.6 \pm 0.9 \\
51.0 \pm 1.7\end{array}$ & $\begin{array}{l}355.0 \pm 52.2 \\
197.1 \pm 3.8\end{array}$ \\
\hline $\begin{array}{l}\text { 2. Cells (fmol/dish) } \\
\text { Medium (fmol/dish } / 24 \mathrm{hr} \text { ) }\end{array}$ & $\mathrm{ND}^{a}$ & $\begin{array}{l}9.3 \\
1.6\end{array}$ & $\begin{array}{l}89.4 \pm 11.6 \\
30.8 \pm 1.1\end{array}$ & $\begin{array}{r}21.2 \pm 4.6 \\
9.4 \pm 0.5\end{array}$ & $\begin{array}{r}191.0 \pm 8.4 \\
57.9 \pm 8.5\end{array}$ \\
\hline $\begin{array}{l}\text { 3. Cells (fmol/dish) } \\
\text { Medium (fmol/dish/24 hr) }\end{array}$ & ND & $\begin{array}{l}266.3 \pm 45.8 \\
131.3 \pm 0.06\end{array}$ & $\begin{array}{l}662.7 \pm 74.2 \\
137.9 \pm 4.1\end{array}$ & $\begin{array}{l}67.0 \pm 4.5 \\
11.8 \pm 0.9\end{array}$ & $\begin{array}{c}210.8 \pm 18.6 \\
44.3 \pm 2.5\end{array}$ \\
\hline $\begin{array}{l}\text { 4. Cells ( } \mathrm{fmol} / \mathrm{dish} \text { ) } \\
\qquad \begin{array}{l}\text { (fmol } / \mu \mathrm{g} \text { of } \mathrm{protein}) \\
\text { Medium (fmol/dish/24 hr) }\end{array}\end{array}$ & $\begin{array}{l}13.3 \pm 2.2 \\
0.04 \pm 0.01\end{array}$ & $\begin{array}{l}25.3 \pm 11.5 \\
0.13 \pm 0.06\end{array}$ & $\begin{aligned} 350.3 & \pm 62.7 \\
0.99 & \pm 0.13 \\
145.8 & \pm 5.7\end{aligned}$ & $\begin{array}{l}21.1 \pm 4.8 \\
0.16 \pm 0.04 \\
2.7 \pm 0.9\end{array}$ & $\begin{array}{r}129.2 \pm 55.2 \\
1.41 \pm 0.70 \\
65.3 \pm 18.3\end{array}$ \\
\hline $\begin{array}{l}\text { 5. Cells (fmol } / \text { dish) } \\
\text { (fmol } / \mu \mathrm{g} \text { of protein) } \\
\text { Medium (fmol } / \text { dish } / 24 \mathrm{hr} \text { ) }\end{array}$ & $\begin{array}{l}\text { ND } \\
\text { ND }\end{array}$ & $\begin{array}{c}2,423 \pm 977 \\
3.53 \pm 1.19 \\
597 \pm 189\end{array}$ & $\begin{aligned} 9,767 & \pm 2,413 \\
9.37 & \pm 2.73 \\
1,193 & \pm 88\end{aligned}$ & $\begin{array}{l}267 \pm 33 \\
0.21 \pm 0.03 \\
47 \pm 15\end{array}$ & $\begin{array}{l}600 \pm 208 \\
0.49 \pm 0.16 \\
140 \pm 71\end{array}$ \\
\hline $\begin{array}{l}\text { 6. Cells (fmol } / \text { dish) } \\
\text { (fmol } / \mu \mathrm{g} \text { of protein) } \\
\text { Medium (fmol } / \text { dish } / 24 \mathrm{hr} \text { ) }\end{array}$ & $\begin{array}{l}\text { ND } \\
\text { ND }\end{array}$ & $\begin{array}{r}5,950 \\
4.99 \\
3,320\end{array}$ & $\begin{array}{r}11,250 \\
9.91 \\
4,845\end{array}$ & $\begin{aligned} 3,733 & \pm 786 \\
2.61 & \pm 0.38 \\
11,737 & \pm 4,186\end{aligned}$ & $\begin{array}{c}5,733 \pm 788 \\
4.39 \pm 0.38 \\
9,737 \pm 3,698\end{array}$ \\
\hline
\end{tabular}

${ }^{a} \mathrm{ND}$, not detectable.

TABLE III

Effects of culture conditions on N'T'-like immunoreactivity in cells and medium from tumor 5

\begin{tabular}{|c|c|c|c|c|c|}
\hline & \multicolumn{5}{|c|}{ Immunoreactive $\mathrm{NT}^{a}$} \\
\hline & \multirow{2}{*}{ Day 0} & \multicolumn{4}{|c|}{ Day 21} \\
\hline & & No Additives & NGF $(100 \mathrm{ng} / \mathrm{ml})$ & Dexamethasone $\left(10^{-5} \mathrm{M}\right)$ & NGF + Dexamethasone \\
\hline Cells (fmol/dish) & $330 \pm 21$ & $590 \pm 202$ & $>1000$ & $29.0 \pm 2.6$ & $117 \pm 12$ \\
\hline (fmol/ $\mu \mathrm{g}$ of protein) & $0.18 \pm .01$ & $0.89 \pm 0.22$ & $>1$ & $0.02 \pm 0$ & $0.01 \pm 0.01$ \\
\hline Medium (fmol/dish/24 hr) & & $9.67 \pm 5.67$ & $114.3 \pm 8.1$ & $\mathrm{ND}^{b}$ & ND \\
\hline
\end{tabular}

${ }^{a}$ Values represent mean $\pm \mathrm{SEM}$ of triplicate dishes.

${ }^{b} \mathrm{ND}$, not detectable.

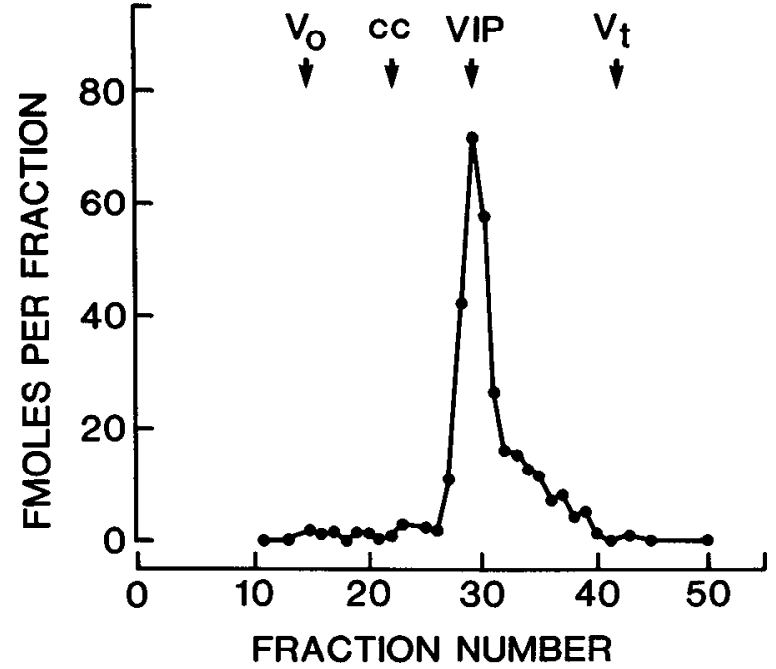

Figure 2. Sephadex gel chromatographic profile of VIPLI in cell extract from NGF-treated cultures of tumor 5 . The column was calibrated with dextran blue $\left(V_{0}\right)$, horse heart cytochrome $c(c c)$, and $\mathrm{Na}^{125} \mathrm{I}\left(V_{t}\right)$ as molecular size markers. VIP indicates the elution position of ${ }^{125}$ I] synthetic VIP. Virtually all of the VIPLI is in a single peak which co-elutes with synthetic VIP. one hundred fiftieth to one-two hundred fiftieth per dish (Table IV). In one case (tumor 2), catecholamine content decreased to undetectable levels. NGF produced either no changes or small decreases in catecholamine content, and dexamethasone produced variable effects. In one case (tumor 5) dexamethasone produced approximately a 2-fold increase in total catecholamine content and a 14-fold increase in epinephrine/norepinephrine ratio. The effects of dexamethasone on catecholamines in the other tumors were small or insignificant.

\section{Discussion}

We have studied process outgrowth, VIPLI, NTLI, and catecholamine content in freshly dissociated cells and in 21-day-old cultures from six human pheochromocytomas. All of the cultures exhibited spontaneous process outgrowth and produced VIPLI. NGF stimulated process outgrowth and enhanced production of VIPLI. Dexamethasone inhibited process outgrowth and tended to decrease production of VIPLI. NTLI was detected in cells from only one of the tumors, and its production appeared to be regulated comparably to that of VIPLI. Catecholamine content decreased markedly in all of the 


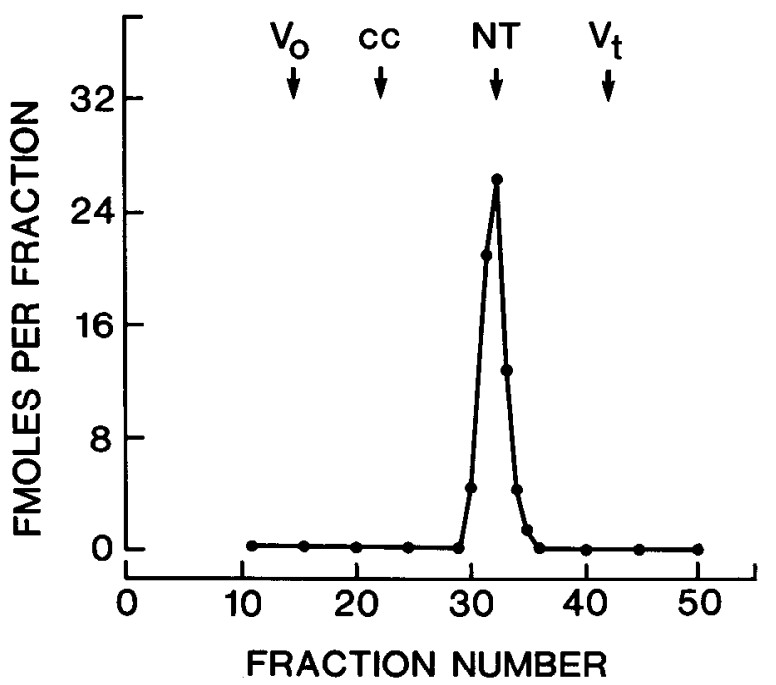

Figure 3. Sephadex gel chromatographic profile of NTLI in cell extract from NGF-treated cultures of tumor 5. NT indicates the elution position of $\left[{ }^{125} \mathrm{I}\right]$ synthetic NT. Virtually all of the NTLI is in a single peak which co-elutes with synthetic NT.

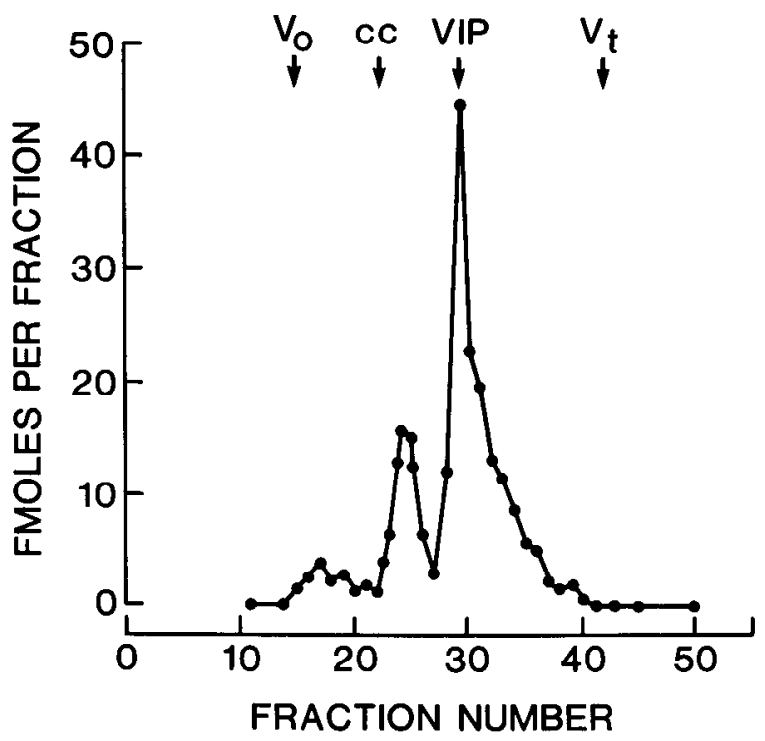

Figure 4. Sephadex gel chromatographic profile of VIPLI in cell extract from NGF-treated cultures of tumor 6 . The VIPLI is in two peaks containing $74 \%$ and $26 \%$ of the total. The former co-elutes with synthetic VIP, and the latter consists of larger molecular forms.

cultures and was not regulated in parallel with either VIPLI or NTLI.

Our most salient finding is that production of VIPLI by cells from all six tumors could be dramatically enhanced or suppressed in response to changes in milieu. This observation suggests that capacity for VIP production is a characteristic which is latent or is expressed at low levels in many human pheochromocytomas and is regulated in response to environmental signals. In general, signals which favor production of VIPLI also favor process outgrowth in monolayer culture. However, the finding that dexamethasone inhibited process outgrowth while increasing production of VIPLI in cultures of tu- mor 2 suggests that regulation of process outgrowth and of VIP production can be dissociated. Process outgrowth and enhanced production of VIPLI have been previously noted in cultures of human paragangliomas, tumors which are similar to pheochromocytomas developmentally and functionally (Tischler et al., 1981). To our knowledge, these are the first reported instances in which production of a clinically significant ectopic peptide by tumor cells has been shown to be subject to external control.

The presence of N'ILI in cells from one of six human pheochromocytomas suggests that NT is an occasional, previously unreported, marker produced ectopically in these tumors. Since NT appears to be unusual in human pheochromocytomas, however, production of the peptide by $\mathrm{PC} 12$ cells more likely reflects a characteristic of rat chromaffin cells than of neoplastic chromaffin cells per se. Furthermore, the content of NT in human pheochromocytoma cells appeared to be regulated differently than in PC12 cells. While $10^{-5}$ dexamethasone increases NT content in PC12 cells (Tischler et al., 1982a, 1983b, c), this concentration of dexamethasone decreased the content of NTLI in the present study. The mechanisms by which dexamethasone might inhibit production of ectopic NTLI by human pheochromocytoma cells is at present unknown. However, it may be of interest that dexamethasone also inhibited process formation by these cells but does not exert this effect on PC12 cells (Tischler and Greene, 1975).

Decreases in catecholamine content comparable to those in this study have previously been noted in longterm cultures of normal adult rat chromaffin cells (Tischler et al., 1982b). In the normal chromaffin cell cultures, however, dexamethasone consistently increases cathecholamine content and the epinephrine/norepinephrine ratio. The absence of consistent effects of dexamethasone on catecholamine content in this investigation is at present unexplained. In studies of additional cultures of one of the tumors in which catecholamine content did not increase in response to dexamethasone (tumor 6), however, we have noted large increases in choline acetyltransferase activity after 21 days in vitro (Tischler et al., 1983b, c). Studies of additional tumors may shed light on the significance of this apparent switch toward cholinergic function.

While we have detected VIPLI in freshly dissociated cells from two of six human pheochromocytomas, Eiden et al. (1982) recently reported VIPLI in extracts of tissue from all of six such tumors. One possible source of this discrepancy is that the aliquots of dissociated cells which we assayed may have contained amounts of VIPLI below the detection limit of the radioimmunoassay. Another possibility is that the VIPLI measured by Eiden et al. may not have all been present in tumor cells. The adrenal medulla is richly innervated with VIP-containing nerve fibers (Linnoila et al., 1980). It is known that many human adrenal masses diagnosed as pheochromocytomas in fact represent extreme degrees of nodular hyperplasia (DeLellis et al., 1976), and residual nerve fibers within or between hyperplastic nodules might to some extent account for more frequent detection of VIPLI in tissue extracts than in dissociated cells. In either case, however, 
TABLE IV

Effects of culture conditions on cellular catecholamine content

Values for epinephrine (E), norepinephrine (NE), and dopamine (DA) represent mean \pm SEM of triplicate dishes or mean of duplicate dishes. In contrast to increases in VIPLI (Table II) or NTLI (Table III), concentrations of catecholamines in the same cultures decrease markedly after 21 days in vitro and are unaffected by NGF. Dexamethasone causes relatively small changes or no changes in catecholamine content except in case 5, where there is a large increase in $\mathrm{E} / \mathrm{NE}$. Catecholamines were measured by high pressure liquid chromatography with electrochemical detection.

\begin{tabular}{|c|c|c|c|c|c|}
\hline \multirow{3}{*}{ Tumor } & \multicolumn{5}{|c|}{ Catecholamine Content } \\
\hline & \multirow{2}{*}{ Day 0} & \multicolumn{4}{|c|}{ Day 21} \\
\hline & & No Additives & NGF $(100 \mathrm{ng} / \mathrm{ml})$ & Dexamethasone $\left(10^{-5} \mathrm{M}\right)$ & NGF + Dexamethasone \\
\hline \multirow{3}{*}{$\begin{array}{l}\text { 1. E } 7,865 \pm 769 \\
\text { NE } 8,213 \pm 789 \\
\text { DA } 243 \pm 18 \\
\text { Total } 16,321\end{array}$} & $\mathrm{pmol} / \mathrm{dish}$ & 51 & $33 \pm 6$ & $54 \pm 6$ & $38 \pm 8$ \\
\hline & $\mathrm{pmol} / \mathrm{dish}$ & 14 & $15 \pm 2$ & $26 \pm 6$ & $50 \pm 5$ \\
\hline & & 91 & 69 & 121 & 130 \\
\hline \multirow{2}{*}{$\begin{array}{l}\text { 2. E } 177 \pm 6 \\
\text { NE } 474 \pm 17 \\
\text { DA } 80 \pm 2 \\
\text { Total } 731\end{array}$} & $\mathrm{pmol} / \mathrm{dish}$ & ND & ND & ND & ND \\
\hline & & ND & ND & ND & ND \\
\hline \multirow{4}{*}{$\begin{array}{l}\text { 3. E } 3,245 \pm 84 \\
\text { NE } 7,637 \pm 225 \\
\text { DA } 228 \pm 20 \\
\text { Total } 11,110\end{array}$} & $\mathrm{pmol} / \mathrm{dish}$ & $34.5 \pm 3$ & $33 \pm 3$ & $42 \pm 23$ & 17 \\
\hline & $\mathrm{pmol} / \mathrm{dish}$ & $40.5+12$ & $39 \pm 6$ & $20 \pm 3$ & 12 \\
\hline & $\mathrm{pmol} / \mathrm{dish}$ & ND & ND & ND & ND \\
\hline & & 75 & 72 & 62 & 29 \\
\hline \multirow{4}{*}{$\begin{array}{l}\text { 5. E } \\
\text { NE } \\
\text { DA } \\
\text { Total }\end{array}$} & $\mathrm{pmol} / \mu \mathrm{g}$ of protein & $3.0 \pm 0.7$ & $2.0 \pm 0.3$ & $17.4 \pm 1.0$ & $17.4 \pm 1.1$ \\
\hline & $\mathrm{pmol} / \mu \mathrm{g}$ of protein & $8.6 \pm 0.4$ & $8.5 \pm 1.3$ & $5.0 \pm 0.0$ & $4.0 \pm 0.3$ \\
\hline & $\mathrm{pmol} / \mu \mathrm{g}$ of protein & $2.5 \pm 0.4$ & $3.4 \pm 0.4$ & $6.0 \pm 0.4$ & $6.3 \pm 0.6$ \\
\hline & $\mathrm{pmol} / \mu \mathrm{g}$ of protein & 14.1 & 13.9 & 28.4 & 27.7 \\
\hline \multirow{4}{*}{$\begin{array}{l}\text { 6. } \mathrm{E} 108 \pm 14 \\
\mathrm{NE} 174 \pm 21 \\
\text { DA } 3.3 \pm 0.6 \\
\text { Total } 285\end{array}$} & $\mathrm{pmol} / \mu \mathrm{g}$ of protein & 0.72 & 0.65 & $0.30 \pm 0.13$ & $0.43 \pm 0.24$ \\
\hline & $\mathrm{pmol} / \mu \mathrm{g}$ of protein & 20 & 19 & $4.60 \pm 0.96$ & $6.01 \pm 1.27$ \\
\hline & $\mathrm{pmol} / \mu \mathrm{g}$ of protein & 13.6 & 18.3 & $10.6 \pm 2.0$ & $13.6 \pm 1.2$ \\
\hline & & 34.3 & 38.0 & 15.5 & 20.0 \\
\hline
\end{tabular}

${ }^{a} \mathrm{ND}$, not detectable.

the findings of Eiden et al., as well as our own observations, indicate that VIPLI is frequently found in human pheochromocytomas in quantities insufficient to produce a clinical syndrome.

Our findings suggest that human pheochromocytoma cell cultures might serve as experimental models to provide insights into cellular and molecular mechanisms in the pathogenesis of ectopic VIP syndromes and possibly into normal regulation of VIP gene expression. Like pheochromocytoma cells, normal adult human chromaffin cells in culture exhibit process outgrowth which is stimulated by NGF and diminished by dexamethasone (Tischler et al., 1980, 1983a). It will be of interest to learn whether normal human chromaffin cells in culture also produce VIP.

\section{References}

Bernard, P., J. Lebras, J. Prodel, A. C. Viguer, P. Curet, and J. Grellet (1980) Exploration angiographique d'un cas d'apudome surrenalien a triple composante hormonale. J. Radiol. 61: 121-124.

Blackburn, A. M., and S. R. Bloom (1979) A radioimmunoassay for neurotensin in human plasma. J. Endocrinol. 83: 175181.

Bornstein, M. B. (1958) Reconstituted rat-tail collagen used as a substrate for tissue cultures on coverslips in Maximow slides and roller tubes. Lab. Invest. 7: 134-137.

Bradford, M. M (1976) A rapid and sensitive method for the quantitation of microgram quantities of protein utilizing the principle of protein-dye binding. Anal. Biochem. 72: 248254.

DeLellis, R. A., H. J. Wolfe, R. F. Gagel, Z. Feldman, H. H. Miller, D. L. Gang, and S. Reichlin (1976) Adrenal medullary hyperplasia. A morphometric analysis in patients with familial medullary thyroid carcinoma. Am. J. Pathol. 83: 177196.

Eiden, L. E., P. Giraud, A. Hotchkiss, and M. J. Brownstein (1982) Enkephalins and VIP in human pheochromocytomas and bovine adrenal chromaffin cells. In Regulatory Peptides: from Molecular Biology to Function, E. Costa and M. Trabucchi, eds., pp. 387-395, Raven Press, New York.

Erny, R. E., M. W. Berezo, and R. L. Perlman (1981) Activation of tyrosine 3-monooxygenase in pheochromocytoma cells by adenosine. J. Biol. Chem. 256: 1335-1339.

Greene, L. A., and A. S. Tischler (1976) Establishment of a noradrenergic clonal line of rat adrenal pheochromocytoma cells which respond to nerve growth factor. Proc. Natl. Acad. Sci. U. S. A. 73: 2424-2428.

Leeman, S. E., and R. E. Carraway (1982) Neurotensin. Ann. N. Y. Acad. Sci. 400: 1-16.

Linnoila, R. I., R. P. Diaugustine, A. Hervonen, and R. J. Miller (1980) Distribution of $\left[\mathrm{Met}^{5}\right]$ and $\left[\mathrm{Leu}^{5}\right]$-enkephalin, VIP, and substance P-like immunoreactivity in human adrenal glands. Neuroscience 5: 2247-2259.

Mendelsohn, G., J. C. Eggleston, J. L. Olson, S. I. Said, and S. B. Baylin (1979) Vascoactive intestinal peptide and its relationship to ganglion cell differentiation in neuroblastic tumors. Lab. Invest. 41: 144-149. 
Mitchell, S. J., and S. R. Bloom (1978) Measurement of fasting and postprandial VIP in man. Gut 19: 1043-1048.

Rokaeus, A., G. Fried, and J. M. Lundberg (1982) Neurotensinlike immunoreactivity (NTLI) in adrenal medulla: Localization, quantitation, characterization, subcellular fractionation and release upon splanchnic nerve activation. Ann. N. Y. Acad. Sci. 400: 389-391.

Said, S. I. (1976) Evidence for secretion of vasoactive intestinal peptide by tumors of pancreas, adrenal medulla, thyroid and lung: Support for the unifying APUD concept. J. Clin. Endocrinol. 5: 201S-204S.

Said, S. I. (1982) Vasoactive Intestinal Peptide, Raven Press, New York.

Spector, T. (1978) Refinement of the Coomassie blue method of protein quantitation. Anal. Biochem. 86: 146-156.

Tischler, A. S., and L. A. Greene (1975) Nerve growth factorinduced process formation by cultured rat pheochromocytoma cells. Nature 258: 341-342.

Tischler, A. S., M. A. Dichter, B. Biales, R. A. DeLellis, and H. J. Wolfe (1976) Neuronal properties of cultured human endocrine tumor cells of proposed neural crest origin. Science 192: 902-904.

Tischler, A. S., R. A. DeLellis, B. Biales, G. Nunnemacher, V. Carabba, and H. J. Wolfe (1980) Nerve growth factor-induced neurite outgrowth from normal human chromaffin cells. Lab. Invest. 43: 399-409.

Tischler, A. S., A. K. Lee, G. Nunnemacher, S. I. Said, R. A. DeLellis, G. M. Morse, and H. J. Wolfe (1981) Spontaneous neurite outgrowth and vasoactive intestinal peptide-like im- munoreactivity in cultures of human paraganglioma cells from the glomus jugulare. Cell Tissue Res. 219: 543-555.

Tischler, A. S., Y. C. Lee, V. W. Slayton, and S. R. Bloom (1982a) Content and release of neurotensin in PC12 pheochromocytoma cell cultures: Modulation by dexamethasone and nerve growth factor. Regul. Peptides 3: 415-421.

Tischler, A. S., R. L. Perlman, G. Nunnemacher, G. M. Morse, R. A. DeLellis, and H. J. Wolfe (1982b) Long-term effects of dexamethasone and nerve growth factor on adrenal medullary cells cultured from young adult rats. Cell Tissue Res. 225: 525-542.

Tischler, A. S., R. A. DeLellis, V. W. Slayton, M. Blount, and H. J. Wolfe (1983a) Enkephalin-like immunoreactivity in human adrenal medullary cultures. Lab. Invest. 48: 13-18.

Tischler, A. S., Y. C. Lee, R. L. Perlman, J. E. Jumblatt, and S. R. Bloom (1983b) Transmitter phenotypic plasticity in human pheochromocytoma cell cultures. Soc. Neurosci. Abstr. 9: 305 .

Tischler, A. S., Y. C. Lee, V. W. Slayton, and S. R. Bloom (1983c) Kinetics of regulation of neurotensin content in PC12 cells. Life Sci. 33: 347-351.

Tischler, A. S., R. L. Perlman, G. M. Morse, and B. E. Sheard (1983d) Glucocorticoids increase catecholamine synthesis and storage in PC12 pheochromocytoma cell cultures. J. Neurochem. 40: 364-370.

Verner, J. V., and A. B. Morrison (1958) Islet cell tumor and a syndrome of refractory watery diarrhea and hypokalemia. Arch. Intern. Med. 133: 492-500. 